\title{
MACHADO DE ASSIS E O ENIGMA DO DESEJO
}

\author{
Sérgio Nazar David \\ Universidade do Estado do Rio de Janeiro
}

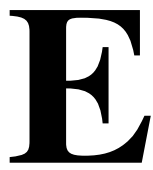

m sua introdução ao terceiro volume da História da vida privada, Nicolau Sevcenko faz referência à raiz do que sabemos ser a expansão da economia capitalista em fins do século XIX:

A raiz dessa dinâmica expansionista foi a irrupção, em fins da século XVIII, em redor de 1780 , da Revolução Industrial. Esse surto inaugural da economia industrializada fora baseada em três fatores básicos: o ferro, o carvão e as máquinas a vapor, propiciando o surgimento das primeiras unidades produtivas, as fábricas. Seu centro de origem e irradiação fora a Inglaterra, e ele esteve voltado sobretudo para a produção de tecidos manufaturados de algodão e lã, distribuídos em escala mundial pelas ferrovias e navios a vapor.

O momento seguinte da expansão da economia industrial, e aquele que mais diretamente nos interessa aqui, foi desencadeado pelo advento da chamada Segunda Revolução Industrial, também intitulada Revolução Científico-Tecnológica, ocorrida de meados do século à sua plena configuração em 1870. Apesar de ser comumente denominada de "segundo momento da industrialização", a Revolução CientíficoTecnológica na realidade é muito mais complexa, ampla e profunda do que um mero desdobramento da primeira, como o nome poderia sugerir. Ela representava de fato um salto enorme, tanto em termos qualitativos quanto quantitativos, em relação à primeira manifestação da economia mecanizada. Resultado da aplicação das mais recentes descobertas científicas aos processos produtivos, ela possibilitou o desenvolvimento de novos potenciais energéticos, como a eletricidade e os derivados de petróleo, dando assim origem a novos campos de exploração industrial, como os altos-fornos, as indústrias químicas, novos ramos metalúrgicos, como os do alumínio, do níquel, do cobre e dos aços especiais, além de desenvolvimentos nas áreas de 
microbiologia, bacteriologia e da bioquímica, com efeitos dramáticos sobre a produção e conservação de alimentos, ou na farmacologia, medicina, higiene e profilaxia, com um impacto decisivo sobre o controle das moléstias, a natalidade e o prolongamento da vida. ${ }^{1}$

Inserir o Brasil nisto que parece ser a marcha do mundo, implica inicialmente voltar as costas para o nosso passado colonial e escravocrata, fazer de conta que não tínhamos que nos haver com esta história da qual pouco, já então, havia para nos orgulharmos. O mesmo tempo que corria cada vez mais rápido também mostraria de modo cada vez mais evidente o quanto o progresso e a ciência nem explicavam tudo e nem eram para todos. Vejamos Machado de Assis, em crônica de 25/3/1894:

(...) que é o tempo? É a brisa fresca e preguiçosa de outros anos, ou êste tufão impetuoso que parece apostar com a eletricidade? Não há dúvida que os relógios, depois da morte de López, andam muito mais depressa. ${ }^{2}$

Em 16/10/1892, Machado olha com desconfiança para os bondes elétricos. Afirma mesmo que deixara de falar neles, por não ter assistido à sua inauguração. Depois disso, nem sequer tinha entrado em algum.

Anteontem, porém, indo pela Praia da Lapa, em um bond comum, encontrei um dos elétricos, que descia. Era o primeiro que êstes meus olhos viam andar.

Para não mentir, direi que o que me impressionou, antes da eletricidade, foi o gesto do cocheiro. Os olhos do homem passavam por cima da gente que ia no meu bond, com um grande ar de superioridade. Pôsto que não fôsse feio, não eram as prendas físicas que lhe davam aquêle aspecto. Sentia-se nêle a convicção de que inventara, não só o bond elétrico, mas a própria eletricidade. ${ }^{3}$

Após cruzarem-se os bondes, o cronista segue até quase o fim da linha, quando então estavam no bonde apenas o condutor, o

${ }^{1}$ SEVCENKO, 1998, p. 8-9.

${ }^{2}$ ASSIS, 1959, p. 628, vol. III.

${ }^{3}$ ASSIS, 1959, p. 577, vol. III. 
cocheiro e ele. O condutor e o cocheiro cochilavam. O cronista então ouve uma conversa dos burros. Um deles argumentava que, passando a tração elétrica para todos os bondes, estariam eles livres. Ao que o outro responde:

- O bonde elétrico apenas nos fará mudar de senhor.

- De que modo?

- Nós somos bens de companhia. Quando tudo andar por arames, não somos já precisos, vendem-nos. Passamos naturalmente às carroças (...) onde a nossa vida será um pouco melhor; não que nos falte pancada, mas o dono de um só burro sabe mais o que êle lhe custou. Um dia, a velhice, a lazeira, qualquer cousa que nos torne incapaz, restituir-nos-á a liberdade...

- Enfim!

- Ficaremos soltos, na rua, por pouco tempo, arrancando alguma erva que aí deixem crescer para recreio da vista. Mas que valem duas dentadas de erva, que nem sempre é viçosa? Enfraqueceremos; a idade ou a lazeira ir-nos-á matando, até que, para usar esta metáfora humana, - esticaremos a canela. Então teremos a liberdade de apodrecer. Ao fim de três dias, a vizinhança começa a notar que o burro cheira mal; conversação e queixumes. No quarto dia, um vizinho, mais atrevido, corre aos jornais, conta o fato e pede uma reclamação. No quinto dia sai a reclamação impressa. No sexto dia, aparece um agente, verifica a exatidão da notícia; no sétimo, chega uma carroça, puxada por outro burro, e leva o cadáver. ${ }^{4}$

Machado de Assis nos mostra aqui, a partir de um certo tom de parábola, o quanto os homens naquele momento atribuíam às melhorias materiais trazidas pela ciência um Bem inquestionável, extensivo a todos, uma liberdade sem limites. Na contramão deste rio largo da ciência, Machado constrói sua filosofia de meiasverdades, diferentemente tanto da filosofia dos antigos, de braço dado com a teologia, e também daqueles que o século XIX tantas vezes chamou de "modernos", de braços dados com a ciência, sem abandonar os benefícios da mais uma vez propalada verdadeira fé, expurgada dos vícios da sociedade burguesa, para os românticos,

${ }^{4}$ ASSIS, 1959, p. 578-579, vol. III. 
expurgada dos exageros das revoluções, que, quais desordens atmosféricas, vinham varrendo a Europa. A este respeito lembro as defesas que Balzac e Garrett fizeram da razão e da fé. Lembro também a cena de Madame Bovary, quando Rodolfo e Ema assistem do alto, do primeiro andar da prefeitura, da sala das audiências, ao discurso do Conselheiro Lieuvain, colocando lado a lado a ciência e a religião, qual "novas artérias do corpo do Estado". 5 É contra tudo isso que Machado se põe.

Após uma pausa, o outro burro contrapõe argumentos:

- Tu és lúgubre (...) Não conheces a língua da esperança.

- Pode ser, meu colega; mas a esperança é própria das espécies fracas, como o homem e o gafanhoto; o burro distingue-se pela fortaleza sem-par. A nossa raça é essencialmente filosófica. Ao homem que anda sôbre dous pés, e provàvelmente à águia, que voa alto, cabe a ciência da astronomia. Nós nunca seremos astrônomos; mas a filosofia é nossa. Tôdas as tentativas humanas a êste respeito são perfeitas quimeras. Cada século...6

Neste momento, o cocheiro encurtou as rédeas. Tinham chegado ao fim da linha.

Há, portanto, homens que entendem a linguagem dos burros, homens filósofos de meias-verdades, como os burros, homens descrentes dos grandes dogmas do século que ia chegando ao fim: Igualdade, Liberdade, Fraternidade. Mas não só estes: ciência e civilização, razão, fé e verdade. Machado se contrapõe a um rio largo que vem da tradição filosófica ocidental, negando este lugar da verdade a qualquer sistema de pensamento totalizante. E com isso, já não fez pouco.

Vejamos o comentário que Machado faz, em crônica de 23/10/1892, quando o bonde elétrico atropela e mata dois velhos.

${ }^{5}$ FLAUBERT, 1979, p. 108.

${ }^{6}$ ASSIS, 1959, p. 579, vol. III. 
Tôdas as cousas têm sua filosofia. Se os dous anciãos que o bond elétrico atirou para a eternidade esta semana, houvessem já feito por si mesmos o que lhes fêz o bond, não teriam entestado com o progresso que os eliminou. É duro de dizer; duro e ingênuo, um pouco à La Palisse; mas é verdade. Quando um grande poeta dêste século perdeu a filha, confessou, em versos doloridos, que a criação era uma roda que não podia andar sem esmagar alguém. Por que negaremos a mesma fatalidade aos nossos pobres veículos??

Machado entende muito bem que não há civilização sem barbárie, que a dita civilização é na verdade um investimento de determinados homens em determinados objetos. Estes homens ocupam um lugar, que lhes é outorgado pelo poder, mas que também lhes outorga poder, como, por exemplo, o de usar a propaganda para impor estes objetos e associá-los a um modo de gozo. Trata-se de uma imposição imperativa. Portanto, isto significa que sempre há perda por um lado, perda em relação ao desejo, e ganho por outro, ganho em relação a um gozo. Portanto, não há progresso, no sentido que certo iluminismo o fixou. Toda sociedade tem forças que se organizam privilegiando o que é qualificado como um bem, um bem suposto para todos, um bem que hipoteticamente todos poderiam alcançar lutando, um bem que anula as particularidades do sujeito. Logo, até para possuir esse "bem", é preciso haver renúncia, algo terá que ser perdido por aqueles que lutam. E alguém também terá que perder. E não me venham dizer que este é um pensamento conservador, porque não estou aqui defendendo o imperativo perverso de que tudo dá no mesmo. Mas sim que será sempre preciso fazer escolhas. E escolhas têm preço. É por isso que, na semana em que se inauguram os bondes elétricos, Machado de Assis deixa de falar deles, para se ocupar da morte de Renan.

Eis aí uma semana cheia. Projetos e projetos, bancários, debates e debates financeiros, prisão de diretores de companhias, denúncia de outros, dous mil comerciantes marchando para o palácio Itamarati, a pé,

${ }^{7}$ ASSIS, 1959, p. 579, vol. III. 
debaixo d'água, processo Maria Antônia, fusão de bancos, alça rápida de câmbio, tudo isso grave, soturno, trágico ou simplesmente enfadonho. Uma só nota idílica, entre tanta cousa grave, soturna, trágica ou simplesmente enfadonha; foi a morte de Renan. ${ }^{8}$

Ao deixar de lado o que o senso comum considera importante, ao fazer de tema de sua crônica a morte de um filósofo, Machado faz algo que parece ter se firmado como uma das marcas dos grandes cronistas: fazer filosofia, questionar as verdades estabelecidas, o curso dos acontecimentos, as notícias a que o jornal dá destaque, o próprio tom das notícias e a posição que aqueles que escrevem têm ao escrever. Machado faz filosofia, faz crônica filosófica porque vai à raiz do ato de filosofar, porque aqui também quer dar um piparote no leitor, e descompromissar-se com as opiniões correntes, com as crenças dominantes de seu tempo, sejam estas os sistemas filosóficos totalizantes, sejam estas as leis do capitalismo, que não quer saber de filosofia, porque o que quer é enfiar dinheiro no bolso.

Não faço análises que me não competem, nem cito obras, nem componho biografia. O jornalismo desta capital mostrou já o que valia o autor de tantos e tão adoráveis livros, falou daquele estilo incomparável, puro e sólido, feito de cristal e melodia. Nada disso me cabe. A rigor, nem me cabe cuidar da morte. Cuidei desta por ser a única nota idílica, entre tanta cousa grave, soturna, trágica ou simplesmente enfadonha.

Em verdade, que posso eu dizer das cousas pesadas e duras de uma semana, remendada de códigos e praxistas, a ponto de algarismo e citações? Prisões, que tenho eu com elas? Processos, que tenho eu com êles? Não dirijo companhia alguma, nem anônima, nem pseudônima; não fundei bancos, nem me disponho a fundá-los; e, de tôdas as cousas dêste mundo e do outro, a que menos entendo, é o câmbio. Não é que lhe negue o direito de subir; mas tantas lástimas ouvi pela queda, quantas ouço agora pela ascensão, - não sei se às mesmas pessoas, mas com êstes mesmos ouvidos.

${ }^{8}$ ASSIS, 1959, p. 575-576, vol. III. 
Finanças das finanças, são tudo finanças. Para onde quer que me volte, dou com a incandescente questão do dia. Conheço já o vocabulário, mas não sei ainda tôdas as idéias a que as palavras correspondem, e, quanto aos fenômenos, basta dizer que cada um dêles tem três explicações verdadeiras e uma falsa. Melhor é crer tudo. A dúvida não é aqui sabedoria, porque traz debate ríspido, debate traz balança de comércio, por um lado, e excesso de demissões por outro, e, afinal, um fastio que nunca mais acaba.?

A morte de Renan, com o significado que passa a ter para o cronista, o faz intervir na matéria do jornal, na contramão dos acontecimentos, e questionar as ilusões do capitalismo, que, porque são ilusões, são falsas. Machado lembra um dos prefácios do filófoso: "J'ai tout critiqué, et, quoi qu'on en dise, y j'ai tout maintenu".

As ressalvas feitas por Machado de Assis ao progresso, as críticas severas que faz aos homens, considerados, tantas vezes - mas não todas - fracos diante do poder do dinheiro, toda esta maré ácida de desilusão tem posto os leitores de Machado, mesmo os seus mais fervorosos admiradores, também desconfiados. Vale então a provocação: o que resta ao homem então, já que o progresso não é o que se pensava, já que a civilização exige sempre muito de nós, ${ }^{10}$ e pagamos sempre caro pelo pouco que ela nos dá? Machado responde a isso?

A resposta a isto só pode estar, a meu ver, naquilo que Freud nos aponta em Mal-estar na civilização: que "a felicidade é, para nós, o que deve ser proposto como termo a toda busca, por mais

\footnotetext{
9 ASSIS, 1959, p. 576-577, vol. III.

${ }^{10}$ LACAN, 1991, p. 47. Cito especificamente: "Qual é a figura nova que nos é fornecida por Freud na oposição princípio de realidade / princípio de prazer? É seguramente uma figura problemática. Freud não pensa nem um instante em identificar a adequação à realidade a um bem qualquer. No Mal-estar na civilização, diz-nos - seguramente a civilização, a cultura pede demais ao sujeito. Se há algo que se chama seu bem e sua felicidade, não há nada para isso ser esperado nem do microcosmo, isto é, dele mesmo, nem do macrocosmo."
} 
ética que seja", "que, para essa felicidade não há absolutamente nada preparado", ${ }^{11}$ no entanto todo homem pode encontrá-la a seu modo. $^{12}$

À primeira vista, pode-se dizer que a busca de uma via, de uma verdade não está ausente de nossa experiência. Pois, que outra coisa procuramos na análise senão uma verdade libertadora?

Mas cuidado, há motivos para não se confiar nas palavras e nas etiquetas. Essa verdade que procuramos numa experiência concreta não é a de uma lei superior. Se a verdade que procuramos é uma verdade libertadora, trata-se de uma verdade que vamos procurar num ponto de sonegação de nosso sujeito. É uma verdade particular. ${ }^{13}$

Não haver uma regra de ouro, um universal para todos - é assim que somos inscritos no simbólico, e nos diferenciamos dos animais. Para o sujeito falante só há o desejo. Este se sustenta numa falta radical. Desejamos o que não há, o que, se existisse, seria o objeto do desejo. Muito embora pela via da fantasia permaneça a crença de que tivemos este objeto e o perdemos. Logo, trata-se de reencontrar o que, sem nunca o termos tido, perdemos. E isto já não é pouco. Portanto, ética, no estrito sentido que a psicanálise a considera, só há a do desejo, entre outros motivos porque ninguém pode saber do meu desejo, ninguém pode saber o que é o bem para o outro. Isto só poderia ser possível se o outro fosse igual a mim, e, como nunca é, tomá-lo por igual é desumanizá-lo, é fazer dele objeto, objeto do meu gozo. Freud nos mostra que o mandamento "Amai ao próximo como a si mesmo" é uma das provas do quanto a civilização precisa controlar a inclinação constitutiva dos seres humanos para a agressividade mútua. E, ao fazê-lo, produz também

${ }^{11}$ LACAN, 1991, p. 23. O ponto principal do capítulo intitulado "Nosso programa" é a importância que Lacan dá ao texto de Freud, o Mal-estar, considerado em relação à tradição filosófica ocidental.

${ }^{12}$ FREUD, 1987, p. 91.

${ }^{13}$ LACAN, 1991, p.35. 
violência. É impossível cumprir este mandamento, porque "todo aquele que, na civilização atual, cumprir tal preceito, só se coloca em desvantagem frente à pessoa que despreza esse preceito". ${ }^{14} \mathrm{E}$ mais: não posso amar ao próximo como a mim mesmo, porque este próximo é diferente de mim. Se o meu amor se pauta numa demanda de igualdade, só poderá, na medida em que a diferença não cessa de se inscrever, esbarrar num muro de ódio, porque o outro não é o que eu dele espero. Tal mandamento é um verdadeiro escândalo.

Volto aqui à pergunta: qual parece ser a posição de Machado diante das grandes narrativas de seu tempo? Já que desconfia da retórica romântica, da disciplina médica higienista, do progresso, da ciência, nos moldes como o senso comum de seu tempo os fixaram, que posição subjetiva Machado reserva aos seus personagens? Neste caso, não há uma posição única. Há aqueles, por exemplo, que são de outro tempo, mas que, por tédio à controvérsia, instalaram-se na aposentadoria, no ceticismo indulgente ${ }^{15}$ - é o caso de Aires. Há outros que agem como Bentinho, o "queridinho da mamãe", que não se consegue ver como objeto-causa do desejo de Capitu, portanto só lhe restando transformá-la em puta, em traidora, só lhe restando ver o rosto de Escobar no de Ezequiel. É impossível atar as duas pontas da vida. Mas esta certeza, este saber sob a forma de certeza não lhe dá acesso ao seu desejo. Pelo contrário, imobilizado, acorrentado, atormentado por inquietas sombras, o drama final de Bentinho, depois Dom Casmurro, é uma extensão da própria vida que levou. Seu lugar é o de resto, a serviço do desejo do Outro. Bentinho escreve. Gasta o tempo em "hortar, jardinar e ler", come bem e não dorme mal. Está o tempo todo diante do que lhe falta, empenhado em reconstruir, explicar, convencer, argumentar,

${ }^{14}$ FREUD, 1987, p. 145.

${ }^{15}$ MURICY, 1988, p. 91: "Livrou-se assim dos conflitos, do drama de Rubião. Aires computa alegremente ou, ao menos, serenamente, o tempo que perdeu. Nesse sentido, escreve seu Memorial, contra a pressa da sua época, contra o gosto de sua época. Sutil discordância de um 'entediado' do século." 
relacionar (a casa de Matacavalos / a casa do Engenho Novo; a Capitu adulta / a Capitu menina; Ezequiel / Escobar). Refugiado no gozo, no bem-estar do corpo, Bentinho escreve, mas o que escreve só sai da banalidade porque há ali em seu relato um narrador-outro que expõe sua dor guardada.

Citei os exemplos de Aires e de Bentinho. Lembro também de Rubião. Kátia Muricy faz cuidadosa leitura de Quincas Borba, em A razão cética, em capítulo intitulado "O legado da desrazão":

Quincas Borba permite aprofundar melhor o que se chamou de construção cética de Machado diante do otimismo liberal em relação à nova moral burguesa.

O legado de Quincas Borba faz de Rubião, um acanhado professor, o adulado capitalista de criado espanhol e cozinheiro francês. O humanitismo justifica a transformação: a evolução - neste caso, o testamento de Quincas Borba - abriu espaço para uma nova razão, a do capital. É diante dessa nova razão que Rubião se perde - ele perde a razão. Incapaz de entrar na nova racionalidade, estranho a uma época para a qual sua razão é pré-moderna, só resta a Rubião o delírio. E, é bem significativo que, nesse delírio, Rubião se identifique a Napoleão ou a Luís Napoleão, os arautos da modernidade. Mais do que incorporar à sua vida doméstica os requintes da burguesia, criados europeus ou chinelas tunisianas, Rubião habita, em seu delírio, as Tulherias. Mais do que descansar à sombra das conquistas da civilização, ele é o conquistador, Napoleão. Excluído da nova ordem por errar nos limites de códigos sociais anacrônicos, Rubião aponta na loucura para a invenção recente dessa razão. E é porque ele não compreende as novas normas sociais que não se dá conta da superficialidade dos jogos de sedução de Sofia, da falsidade da amizade de Palha ou de Camacho. Rubião é um tolo, mas só na medida em que é um deslocado, um anacrônico. ${ }^{16}$

O curioso é que a posição destes personagens não é determinada pelo mundo, pela lógica do capitalismo. Eles estão onde estão, mas não sem alguma implicação subjetiva.

${ }^{16}$ MURICY, 1888, p. 88. 
O ritmo cada vez mais febril da cidade, as ilusões do passado, que ainda têm um lugar no mundo que surgia, as ilusões do presente, às quais tantos, os mais aptos, os mais cínicos, mas também os tolos, vão se agarrando - tudo isso dita regras, porque para o capitalismo desejar não é preciso, o que é preciso é ter esperança, é esperar tudo, do amor, da ciência, do dinheiro. Colocar-se na posição desejante é correr riscos, pagar pra ver. É o que fazem, por exemplo, aqueles que não são boizinhos de presépio: a Marocas, de "Singular ocorrência"; ou ainda Porfírio, de "Terpsícore".

\section{Observemos o conto Singular ocorrência.}

Dois homens conversam à porta da igreja da Cruz enquanto observam uma mulher que vai entrando. Um deles então conta ao outro que ela devia chamar-se Maria de tal, mas que, em 1860, "florescia com o nome familiar de Marocas". E completa:

- (...) Não era costureira, nem proprietária, nem mestra de meninas; vá excluindo as profissões e lá chegará. Morava na rua do Sacramento. (...) Na rua, com o vestido afogado, escorrido, sem espavento, arrastava a muitos, ainda assim.

- Por exemplo, ao senhor.

- Não, mas ao Andrade, um amigo meu, de vinte e seis anos, meio advogado, meio político, nascido nas Alagoas, e casado na Bahia, donde viera em 1859. Era bonita a mulher dele, afetuosa, meiga e resignada; quando os conheci, tinham uma filhinha de dois anos. ${ }^{17}$

A narração prossegue: como Marocas e o Andrade se conheceram à porta da loja Paula Brito, no Rocio; como se encontraram casualmente à noite no Ginásio onde "dava-se a Dama das Camélias"... ${ }^{18}$ No último ato Marocas chorou como uma criança. A conclusão é rápida:

- Não lhe digo nada; no fim de quinze dias amavam-se loucamente. Marocas despediu todos os seus namorados, e creio que não

\footnotetext{
${ }^{17}$ ASSIS, 1959, p. 386-387, vol. II.

${ }^{18}$ ASSIS, 1959, p. 387, vol. II.
} 
perdeu pouco; tinha alguns capitalistas bem bons. Ficou só, sozinha, vivendo para o Andrade, não querendo outra afeição, não cogitando de nenhum outro interesse.

- Como a Dama das Camélias. ${ }^{19}$

A princípio Marocas parece deixar o lugar da cortesã, para trilhar o caminho da regeneração através do amor: o verdadeiro amor, fora do casamento, fora das convenções sociais, longe dos salões da corte e da rua, espaços que os "capitalistas bem bons" tinham para dedicar-se, respectivamente, às mulheres que o mundo respeita e às que o mundo despreza. ${ }^{20} \mathrm{O}$ dinheiro governava e movia os homens nos dois espaços, como se não lhes restasse escolha. Mas disse "a princípio". Vejamos então o que vai se passar.

O narrador segue contando ao amigo, à porta da igreja, como Marocas aprendeu a ler, e como ele, o próprio narrador, adquirira a confiança de ambos, de Marocas e de Andrade. O romance extraconjugal segue sendo narrado por um personagem, notem, alguém que desfrutou da intimidade do casal, mas que curiosamente não sabe explicar tudo que conta. A narração ensaia passos dentro da previsibilidade do discurso romântico. Tudo parece se encaminhar para uma dita regeneração moral em nome do amor. Certo dia, então, Andrade, no escritório, pouco depois do meio-dia, encontra um tal Leandro:

- (...) Era um sujeito reles e vadio. Vivia a explorar os amigos do antigo patrão. Andrade deu-lhe três mil-réis, e, como o visse excepcionalmente risonho, perguntou-lhe se tinha visto passarinho verde. $\mathrm{O}$ Leandro piscou os olhos e lambeu os beiços: o Andrade, que dava o cavaco por anedotas eróticas, perguntou-lhe se eram amores. Ele mastigou um pouco, e confessou que sim. ${ }^{21}$

\footnotetext{
${ }^{19}$ ASSIS, 1959, p. 387, vol. II.

${ }^{20}$ Expressões que dão títulos a capítulos de Coração, cabeça e estômago (1862), de Camilo Castelo Branco.
}

${ }^{21}$ ASSIS, 1959, p. 388, vol. II. 
E então vem a estória que o tal Leandro contou ao Andrade, e que, volto a repetir, é-nos narrada através de diálogo entre dois amigos na porta da igreja, um dois quais coadjuvante e confidente dos protagonistas à época.

O Leandro tivera na véspera uma fortuna rara. Conhecera certa dama... Parece claro já que tal dama era a Marocas. O Leandro fala da casa dela à rua do Sacramento, e o Andrade...

- (...) não soube o que fez nem o que disse durante os primeiros minutos, nem o que pensou nem o que sentiu. ${ }^{22}$

Curiosamente, aqui o amor não tem nada a ver com o dinheiro. O dinheiro não arrasta as pessoas para onde elas não querem ir. Marocas vai com o Leandro porque quer. Bem assim fora para os braços do Andrade largando alguns "bons capitalistas" pra trás. Juntos, o Andrade e a Marocas, não se ergue entre eles nenhum abismo moral. Quando fica sabendo da estória, o Andrade propõe pagar vinte mil-réis ao Leandro, se este o levasse à casa da moça e dissesse, em presença dela, que era ela mesma a tal.

- (...) Não defendo o Andrade; a cousa não era bonita; mas a paixão, nesse caso, cega os melhores homens. Andrade era digno, generoso, sincero; mas o golpe fora tão profundo, e ele amava-a tanto, que não recuou diante de tal vingança. ${ }^{23}$

O Leandro aceitou. Ambos vão à casa de Marocas. Leandro confirma que é ela mesma, recebe o dinheiro e sai. Andrade diz a Marocas palavras as mais duras do mundo e atira-se em direção à porta, deixando Marocas no chão, lacrimosa, desesperada. O comentário de quem ouve a estória detém-se no Leandro. Quem ouve quer compreender, explicar, talvez insinuando um certo hábito de Marocas, que também talvez mostrasse de modo naturalista que a regeneração completa seria impossível, pois ela trazia na alma a

22 ASSIS, 1959, p. 388, vol. II.

${ }^{23}$ ASSIS, 1959, p. 389, vol. II. 
mancha de sua condição passada. Mas o diálogo desmente esta hipótese. Vejamos:

- (...) ficou atirada ao chão, no patamar da escada; ele desceu vertiginosamente e saiu.

- Na verdade, um sujeito reles, apanhado na rua; provavelmente eram hábitos dela?

- Não. ${ }^{24}$

O que temos aqui é o ato inexplicável para o senso comum, para a moral vigente à época. Não foi por dinheiro, porque o Leandro era um sujeito reles e vadio. Não foi por inclinações morais inapagáveis, porque não eram hábitos dela. Não foi porque a Marocas no fundo de sua alma não amasse verdadeiramente o Andrade, porque depois da aventura com o Leandro viera o desinteresse. O próprio Leandro contara isto ao Andrade. O que temos aqui é o rompimento com o discurso da moral, portador de uma verdade com valor de Dogma. Algo aconteceu que fugiu ao domínio dos protagonistas da cena, que foge aos domínios dos dois homens que conversam anos depois na porta da igreja, mas que nós leitores podemos tibiamente acolher. Algo momentâneo que não poderemos saber de todo. O que aquele encontro furtivo - que aparentemente não se fazia em nome do "verdadeiro amor" e obviamente nem muito menos em nome das leis cristãs do casamento ou as do dinheiro - promoveu de verdade para Marocas? É em torno deste ato distante, deste ponto vazio, desta interrogação que move montanhas que esta "singular ocorrência" se inscreve.

- Meu conselho foi que a deixasse; que, afinal, vivesse para a mulher e a filha, a mulher tão boa, tão meiga... Ele concordava, mas tornava ao furor. Do furor passou à dúvida; chegou a imaginar que a Marocas, com o fim de o experimentar, inventara o artifício e pagara ao Leandro para vir dizer-lhe aquilo; e a prova é que o Leandro, não querendo ele saber quem era, teimou e lhe disse a casa e o número. $\mathrm{E}$

${ }^{24}$ ASSIS, 1959, p. 389, vol. II. 
agarrado a esta inverossimilhança, tentava fugir à realidade; mas a realidade vinha, - a palidez de Marocas, a alegria sincera do Leandro, tudo o que lhe dizia que a aventura era certa. Creio até que ele arrependia-se de ter ido tão longe. Quanto a mim, cogitava na aventura, sem atinar com a explicação. Tão modesta! maneiras tão acanhadas!

- Há uma frase do teatro que pode explicar a aventura, uma frase de Augier, creio eu: "a nostalgia da lama".

- Acho que não; mas vá ouvindo. ${ }^{25}$

A expectativa romântica arma-se em torno do discurso da moral vigente, enquanto Verdade Absoluta. Alguém, porque viveu os fatos que vai narrar, traz para si a narração e a explicação dos fatos. A previsibilidade é a nota certa da falta de transversalidade das narrativas da época, com as quais Machado dialoga. No entanto, no conto de Machado as coisas já começam mal quando a narração é construída como um falso teatro. Se não temos a verdade dos fatos ocorridos à época dos amores de Marocas com o Andrade narrados por um certo alguém que sabe o que diz, temos em contrapartida o ponto vazio do narrador que outorga o seu lugar a um Outro. O que teremos não será a vida como ela foi, não será o drama da vida real, não será o poeta conduzindo seu espelho como um reformador, a apontar à sociedade seus vícios e suas virtudes para corrigila. Aqui, em "Singular ocorrência", o drama dos homens parece ser - viver sem garantias. E o vivido, e depois narrado (por um outro a uma terceira pessoa antes de nós, leitores), ao contrário do que pensávamos, não é uma engenhosa teia de pressupostos, seguida de resultados, conseqüências, repetições, revelações sem senões àqueles que quiserem fazer igual.

Marocas sumiu no mundo. Mas não se matou. Andrade prometeu matar-se. Mas não se matou. Ela acabou sendo encontrada numa hospedaria, no Jardim Botânico. Andrade e o amigo, agora narrador dos fatos, rumam para lá. O dono da hospedaria confirma tudo e leva-os até o quarto.

${ }^{25}$ ASSIS, 1959, p. 390, vol. II. 
- (...) Encaminhamo-nos para o quarto; o dono da hospedaria bateu à porta; ela respondeu com voz fraca, e abriu. O Andrade nem me deu tempo de preparar nada; empurrou-me, e caíram nos braços um do outro. Marocas chorou muito e perdeu os sentidos.

- Tudo se explicou?

- Cousa nenhuma. Nenhum deles tornou ao assunto; livres de um naufrágio, não quiseram saber nada da tempestade que os meteu a pique. ${ }^{26}$

Marocas dá-lhe um filho, que morre com dois anos. Andrade faz viagem para a província e morre por lá. Marocas põe luto, considera-se viúva, ouve missa nos três primeiros anos.

- Há dez anos perdi-a de vista. Que lhe parece tudo isto?

- Realmente, há ocorrências bem singulares, se o senhor não abusou da minha ingenuidade para imaginar um romance...

- Não inventei nada; é a realidade pura.

- Pois, senhor, é curioso. No meio de uma paixão ardente, tão sincera... Eu ainda estou na minha; acho que foi a nostalgia da lama.

- Não: nunca a Marocas desceu até os Leandros.

- Então por que desceria naquela noite?

- Era um homem que ela supunha separado, por um abismo, de todas as suas relações pessoais; daí a confiança. Mas o acaso, que é um deus e um diabo ao mesmo tempo... Enfim, cousas! ${ }^{27}$

Se houve a tal nostalgia da lama, aqui não está em jogo nenhuma conotação moral. Marocas não reafirmou uma suposta verdadeira natureza. Também não retorna ao que, talvez supusessem alguns, nunca tivesse deixado de ser. Nada disso. A lama não é a descida ao mundo ignaro que a corrompera no passado. Se os interlocutores consideram este sentido surrado pela ficção romântica, então talvez mais uma vez não saibam o alcance do que dizem. E lama enquanto escória social, que é o sentido que o capitalismo dá ao termo, isto também não é o que a moveu em direção ao Leandro. Afinal ela deixara alguns bons capitalistas pelo Andrade. Repito: ela nunca descera aos Leandros. Estamos, mais uma vez, diante de uma versão

\footnotetext{
${ }^{26}$ ASSIS, 1959, p. 390, vol. II.

${ }^{27}$ ASSIS, 1959, p. 391, vol. II.
} 
do homem sobre a mulher. Ela não fala. É falada. E é este moralismo da versão masculina sobre a mulher que sutura o enigma que é a mulher para o homem. Machado deixa vazio o lugar do narrador, mas não deixa de relativizar o discurso masculino que coloca a aventura feminina como algo que só poderia se dar em nome do dinheiro (o que ofereceria um álibi à pobre mulher corrompida pelo mundo) ou em nome de um amor acima de todas as coisas. ${ }^{28} \mathrm{~A}$ terceira hipótese é a lama. Se está relativizado também este terceiro lugar, é porque há um narrador fictício que lança uma sombra de dúvida sobre o relato. É a ironia deste narrador fictício que transforma o significado moral de lama. Para este narrador fictício, lama é sinônimo de enigma. Portanto, enquanto tal não está associada a retorno a uma vida indigna, à prostituição. Não é desejo de retorno à sociedade primitiva, na suposição ilusória de que, sem os abismos da sociedade de classes, então sim o amor encontrará o espaço que o mundo hostil lhe nega. Lama é metáfora que é colocada no lugar daquilo que os personagens, enquanto representantes da moral da época, não conseguem dar conta. Uma coisa é não haver a inscrição da diferença sexual. Outra coisa é não aceitar este não haver. Lama é uma metáfora cristalizada que se assenta numa moral. Que moral? A moral do cristianismo e do saber médico. Machado revira estes sentidos cristalizados. Diante da própria perplexidade diante do desejo do Outro-sexo, os personagens masculinos de Machado contrapõem uma moral. Isto porque para esta moral vigente as mulheres não podem se posicionar diante do desejo. Não podem fazê-lo, nem como sujeito nem como objeto-causa, restando-lhes portanto o lugar de ser assexuado, e morto para o desejo. É através deste significante lama que fica marcada a impossibilidade definitiva dos homens daquela sociedade falocêntrica de compreender o que quer uma mulher.

Embora insistamos tantas vezes em acreditar em suas juras, e nos entreguemos a elas com apetite tão antigo, como se fosse possível saciá-

\footnotetext{
${ }^{28}$ Vale apontar aqui a leitura moralista que Antonio Candido faz deste conto. Cf. CANDIDO, 1977, p. 27-28.
} 
lo, o amor nos impõe ele mesmo a sua mais dura verdade: é impossível de dois fazer um, é impossível saber tudo sobre ele. E mais: não há o significante que dê conta da diferença sexual. Ao contrário do que supúnhamos, estamos fadados à insatisfação. Marocas, embora amasse o Andrade, foi com o Leandro porque quis, o que, convenhamos, a coloca bem distante das "respeitáveis senhôras" de seu tempo.

Dentro daquela cidade que já se transforma bastante, capital do Brasil do Segundo Império, e que ainda se transformaria mais, a singularidade de amar ensaiará passos às vezes transversos para que o desejo possa abrir seus sulcos e deslizar, sem que com isso se espere a salvação ou a perdição. A ética do desejo é uma verdadeira terceira margem do rio. Governado pelo Leandro, Andrade quer saber toda a verdade, quer desmascarar Marocas - e depois é por isso que tem que pagar vinte mil-réis. Não é à toa que seus atos são descritos neste momento como que ganhando certo feitio teatral. Algo de seu estava sendo perdido ali. O movimento seguinte de Andrade é para esquecer. E esquecer é tudo que aquela sociedade não lhe ensinara. Ao reencontrarem-se, Marocas e o Andrade "caíram nos braços um do outro" e depois "nenhum deles tornou ao assunto".

Vamos agora ao Porfírio, de "Terpsícore".

O conto inicia-se com Porfírio sentado na cama, de manhã, olhando para a parede. E com Glória, sua mulher, "dizendo-lhe carinhosamente que não se amofinasse, que Deus arranjaria as coisas". ${ }^{29}$ O casal deve seis meses de aluguel e está sob a ameaça do senhorio. Diz-lhe Glória:

- Tudo há de acabar bem, Porfírio. Você mesmo acredita que o senhorio bote os nossos trastes no Depósito? Não acredite; eu não acredito. Diz aquilo para ver se a gente arranja o dinheiro.

- Sim, mas é que eu não arranjo, nem sei onde hei de buscar seis meses de aluguel. ${ }^{30}$

${ }^{29}$ ASSIS, 1996, p. 26.

${ }^{30}$ ASSIS, 1996, p. 26. 
Glória pensa em mais uma vez recorrer ao padrinho. E em levar sua mãe, para ajudar no pedido. Porfírio desabafa:

- Diabo! Tanta despesa! Conta em toda a parte! é a venda! é a padaria! é o diabo que os carregue. Não posso mais. Gasto todo o santo dia manejando a ferramenta, e o dinheiro nunca chega. Não posso, Glória, não posso mais... ${ }^{31}$

Quando Porfírio senta-se à mesa de pinho, para comer um pão e tomar café, preparados por Glória, "risonha de esperança para animá-lo", 32 inicia-se um flash-back que abarcará o período que vai desde o dia em que Porfírio e Glória se conheceram até as dívidas posteriores à lua-de-mel, que o retiram da vida de duque, e dos prestígios do amor, arremeçando-o novamente numa rotina de sete, oito horas de trabalho numa loja como marceneiro.

Neste parêntese, Machado nos dá, com pinceladas rápidas, a dimensão do drama do jovem casal. E também a singularidade destes dois neste mundo que caminha cada vez mais rapidamente para as normas médicas e cristãs, para a exclusão da subjetividade, para as soluções, que são de classe, mas que são vendidas como um Bem para todos.

O narrador volta ao momento em que Porfírio conhece Glória. Ela está dançando polca. Porfírio vem passando. E pára, "defronte da janela aberta" ${ }^{33}$ Os momentos finais da dança são assim narrados:

A sala, que era pequena, estava cheia de pares, mas pouco a pouco foram-se todos cansando ou cedendo o passo à Glória.

- Bravos à rainha! exclamou um entusiasta.

Da rua, Porfírio cravou nela uns olhos de sátiro, acompanhou-a em seus movimentos lépidos, graciosos, sensuais, mistura de cisne e de cabrita.

(...)

31 ASSIS, 1996, p. 26-27.

32 ASSIS, 1996, p. 27.

33 ASSIS, 1996, p. 27. 
No dia seguinte (Porfírio) acordou resoluto a namorá-la e desposá-la. Cumpriu a resolução em pouco tempo, parece que um semestre. ${ }^{34}$

O que quero marcar aqui é o quanto a dança, e uma dança popular, a polca, desperta em Porfírio o desejo. E a partir daí ele passa a agir. Namorou, aprendeu a dançar...

(...) tirou dez mil réis mensais à féria do ofício, entrou para um curso de dança, onde aprendeu a valsa, a mazurca, a polca e a quadrilha francesa. Dia sim, dia não, gastava ali duas horas por noite, ao som de um oficlide e de uma flauta, em companhia de alguns rapazes e de meia dúzia de costureiras magras e cansadas. Em pouco tempo estava mestre. ${ }^{35}$

Feito isso, Porfírio tratou de procurar casa. Quando encontrou a casa em que acabou indo morar, não a achou grande, antes pequena, mas os arabescos que adornavam a frontaria da casa "lhe levaram os olhos". ${ }^{36}$ Porfírio não gostou do preço. Regateou. Mas, "vendo que o dono não cedia nada, cedeu tudo". ${ }^{37}$ Depois era cuidar do casamento. E aqui também Porfírio não pagou pouco pelo que queria.

Que poupar despesas? Mas se num dia grande como esse não se gastava alguma coisa, quando é que se havia de gastar? Nada; era moço, era forte, trabalho não lhe metia medo. Contasse ele com um bonito coupé, cavalos brancos, cocheiros de farda até abaixo e galão no chapéu.

E assim se cumpriu tudo; foram bodas de estrondo, muitos carros, baile até de manhã. Nenhum convidado queria acabar de sair; todos forcejavam por fixar esse raio de ouro, como um hiato esplêndido na velha noite do trabalho sem tréguas. ${ }^{38}$

O padrinho de casamento emprestou dinheiro para tudo isso. E nunca cobrou, diz-nos o narrador. Mas o importante em tudo isso é que os gastos e mais gastos não são feitos como ornamento para

\footnotetext{
${ }^{34}$ ASSIS, 1996, p. 27-28.

${ }^{35}$ ASSIS, 1996, p. 28.

${ }^{36}$ ASSIS, 1996, p. 30.

${ }^{37}$ ASSIS, 1996, p. 30.

${ }^{38}$ ASSIS, 1996 , p. $30-31$.
} 
galgar um lugar naquela sociedade, nem para cumprir uma norma social. Os próprios convidados são gente do bairro mesmo, e que tinha ali "um hiato na velha noite de trabalho". Nada aponta para o consumismo, para o luxo, nem muito menos podemos dizer que estamos diante de um "perdulário". A não ser que estejamos, agora sim, do lado das leis do capitalismo, que incentiva a poupança e que acredita que tudo se reduz a dinheiro. Porfírio inverte esta lógica, até porque para ele há muitos modos de se conseguir o que se quer: pedindo ao padrinho, regateando, estudando, trabalhando, ganhando na loteria.

O flash-back termina com Porfírio untando o pão com a manteiga, que já "tem o ranço da miséria que se aproxima". ${ }^{39} \mathrm{E}$ logo sai pra trabalhar. Os contrastes entre os apertos de um homem pobre e o luxo das elites imperiais são marcados também, mais uma vez, através do olhar de Porfírio:

De caminho, [Porfírio] vai olhando para as casas grandes, sem ódio ainda não tem ódio às riquezas -, mas com saudade, uma saudade de coisas que não conhece, de uma vida lustrosa e fácil, toda alagada de gozos infinitos... ${ }^{40}$

De volta à casa, Porfírio encontra Glória abatida. O padrinho negara-lhes ajuda, respondendo-lhe que "eles tinham as mãos rotas, e não dava nada enquanto fossem um par de malucos". ${ }^{41}$ A resposta de Porfírio a Glória é: "- Maluco é ele!"

No sábado, voltando para casa, Porfírio compra um bilhete de loteria. Em casa pergunta à mulher o que ela lhe daria se ele lhe trouxesse naquela semana um vestido de seda.

${ }^{39}$ ASSIS, 1996, p. 32.
${ }^{40}$ ASSIS, 1996, p. 33.
${ }^{41}$ ASSIS, 1996, p. 33.
${ }^{42}$ ASSIS, 1996, p. 33. 
Glória levantou os ombros. Seda não era para eles. E por que é que não havia de ser? Em que é que as outras moças eram melhores que ela? Não fosse ele pobre, e ela andaria de carro...

- Mas é justamente isso, Porfírio; nós não podemos.

Sim, mas Deus às vezes também se lembra da gente (...) E mirando a mulher, com olhos derretidos; despia-lhe o vestido de chita, surrado e desbotado, e substituía-o por outro de seda azul - havia de ser azul -, com fofos ou rendas, mas coisa que mostrasse bem a beleza do corpo da mulher... ${ }^{43}$

Pouco importa que a loteria seja o acaso. O importante é a posição de Porfírio diante daquela sociedade e diante de seu desejo. Não se coloca na posição de vítima e nem na do excluído. Afinal: Deus às vezes também se lembra deles, e Glória não é diferente das outras moças. Portanto, é o poder do dinheiro que, naquele momento, na visão de Porfírio, os embaraça. Diante disso, Porfírio age. Compra o bilhete, vai pra casa sonhando com a beleza do corpo da mulher, "corpo como não há de haver muitos no mundo". ${ }^{44}$ Diz isso a ela, que começa então a rir. Eles lembram-se de como tinham se conhecido, ela "toda dengosa", dançando...

E, falando, [Porfírio] pegou dela pela cintura e começou a dançar com ela, cantarolando uma polca; Glória, arrastada por ele, entrou também a dançar a sério, na sala estreita, sem orquestra nem espectadores. Contas, aluguéis atrasados, nada veio ali dançar com eles. ${ }^{45}$

A lembrança do passado e a dança, sem orquestra nem espectadores, são a via de acesso ao desejo, a trilha aberta em direção a uma realidade adversa. Mas não é em relação a esta que o desejo se sustenta, mas sim porque é à lei, enquanto tal, que este se liga.

Dias depois, um dos bilhetes de Porfírio sai premiado: 500 milréis! Pagas as dívidas, sobraram perto de duzentos réis. Glória quis botar este dinheiro na Caixa. Mas Porfírio compra o vestido de seda.

\footnotetext{
${ }^{43}$ ASSIS, 1996, p. 36.

${ }^{44}$ ASSIS, 1996, p. 36.

${ }^{45}$ ASSIS, 1996, p. 37.
} 
E ainda por cima resolve dar um pagode. Glória opõe-se, mas Porfírio tinha argumentos para sustentar seu desejo.

Era até um modo de agradecer ao Nosso Senhor. Que é que se leva da vida? Todos se divertiam; os mais reles sujeitos achavam um dia de festa; eles é que iam gastar os anos como se fossem escravos? ${ }^{46}$

Glória ainda insiste, tentando dissuadi-lo do propósito do pagode. Propõe estrear o vestido de seda na festa da Glória.

- Uma coisa não impede a outra, disse ele. Não convido muita gente, não; patuscada de família; convido o Firmino e a mulher, as filhas do defunto Ramalho, a comadre Purificação, o Borges... ${ }^{47}$

Os convidados são de família. Em nenhum momento é sugerida a ostentação, mas sim a febre e o delírio da festa.

Chegou o dia. Glória, iscada da febre do marido, vaidosa com o vestido de seda, estava no mesmo grau de entusiasmo. Às vezes, pensava no dinheiro, e recomendava ao marido que se contivesse, que salvasse alguma coisa para pôr na Caixa; ele dizia que sim, mas contava mal, e o dinheiro ia ardendo... Depois de um jantar simples e alegre, começou o baile, que foi de estrondo, tão concorrido que não se podia andar.

Glória era a rainha da noite. O marido, apesar de preocupado com os sapatos - novos e de verniz -, olhava para ela com olhos de autor. $^{48}$

Porfírio comandava tudo, para que a festa não esfriasse. Batia palmas, bradava "que um dia não eram dias, que havia tempo de dormir em casa". ${ }^{49} \mathrm{E}$ o conto se encerra:

Então o oficlide roncava alguma coisa, enquanto as últimas velas expiravam dentro das mangas de vidro e nas arandelas. ${ }^{50}$

\footnotetext{
${ }^{46}$ ASSIS, 1996, p. 42.

${ }^{47}$ ASSIS, 1996, p. 42.

${ }^{48}$ ASSIS, 1996, p. 44.

${ }^{49}$ ASSIS, 1996, p. 45.

${ }^{50}$ ASSIS, 1996, p. 45.
} 
Porfírio sai da posição de refém daquele mundo. A febre, o delírio do casal arrasta os convidados. É um ato que rompe a previsibilidade daquela sociedade imobilista e a própria lógica do capitalismo: Porfírio e Glória, isto já vimos, não são escravos da falta de dinheiro, pois são capazes de dançar sem música, sem convidados e sem platéia, são capazes de recordar o passado, quando ele, Porfírio, passando por uma janela na rua da Imperatriz foi iscado pelo corpo dengoso de Glória polcando. Mas também não são escravos do dinheiro, nem das convenções sociais.

O conto não termina nem com a catástrofe do esbanjador contumaz nem com uma suposta quebra de um mundo ilusório, nem muito menos com a felicidade eterna do casal. A imagem final do conto é um verdadeiro espelho de muitas faces. Evoca os sons da noite, a finitude do desejo, a aventura em aberto e sem transcendência da vida humana.

Glória pôde ser desejada e amada por Porfírio. Talvez exatamente porque não precisou optar entre a santidade e a pureza. Lembro aqui dos olhos de sátiro de Porfírio, ao vê-la pela primeira vez, "mistura de cisne e de cabrita" ${ }^{51}$ Lembro também do exílio de Conceição, dentro da própria casa e da noite de Natal, sem lugar, sem conseguir alcançar uma terceira margem, fora das imagens que aquele mundo cunhava: a de santa e a de puta. ${ }^{52}$

Chamo a atenção para o quanto Machado apontará para a implicação subjetiva de cada um em seus atos. É difícil, sempre, escolher. E isto porque não escolher também é tomar uma posição. Os capitalistas, os conselheiros, a burguesia carioca do fim do Império e início da República, estes normalmente são reféns do mundo com o qual colaboram, com diferentes parcelas de anuência. E a dimensão do desejo talvez se abra justamente para aqueles que estão nas margens: as prostitutas, os pobres marceneiros, as

\footnotetext{
${ }^{51}$ ASSIS, 1996, p. 27.

52 Cf. "Missa do galo". ASSIS, 1959, p. 584-589, vol. II.
} 
caboclinhas de vinte anos, ${ }^{53}$ as crianças. ${ }^{54}$ Os outros são reféns das aparências, como D. Paula, por exemplo, que reconduz a sobrinha à moral cristã dos laços indissolúveis do casamento, enquanto recorda docemente e secretamente um amor do passado vivido fora do casamento. ${ }^{55} \mathrm{Ou}$ ainda o Fortunato, de "A causa secreta", 56 alienado de seu desejo na obrigatoriedade do gozo, no extremo do prazer experimentado como dor, a própria e a alheia. Forçar o acesso à Coisa através da dor (Fortunato), ou aceitar a dor moral como se fosse a sociedade que estivesse impossibilitando o acesso à Coisa (Garcia) - eis o quanto a literatura de Rousseau e de Sade se avizinham, eis o quanto o masoquismo moral do século XIX, no que ele tem de pastoral e de determinista, será revirado por Machado.

Em suma, Kant tem a mesma opinião de Sade. Pois, para atingir absolutamente das Ding, para abrir todas as comportas do desejo, o que Sade nos mostra no horizonte? Essencialmente a dor. A dor de outrem e, igualmente, a dor própria do sujeito, pois são, no caso, uma só e mesma coisa. O extremo do prazer, na medida em que consiste em forçar o acesso à Coisa, nós não podemos suportá-lo. É o que constitui o lado derrisório, o lado - para empregar um termo popular - maníaco que salta a nossos olhos nas construções romanceadas de Sade - a cada instante se manifesta o mal-estar da construção viva, exatamente isso que torna tão difícil, para nossos neuróticos, a confissão de algumas de suas fantasias.

As fantasias, com efeito, num certo grau, num certo limite, não suportam a revelação da fala. ${ }^{57}$

Rousseau será a grande matriz do romantismo francês..$^{8}$ Onde Lacan escreve Kant proponho, com grande margem de risco, que seja lido Rousseau. Kant foi um apaixonado pela obra do mestre de Genebra.

53 Cf. "Noite de almirante". ASSIS, 1959, p. 438-442, vol. II.

${ }^{54}$ Cf. "Conto de escola". ASSIS, 1959, p. 532-537, vol. II.

55 Cf. "Dona Paula". ASSIS, 1959, p. 539-544, vol. II.

56 ASSIS, 1959, p. 498-504, vol. II.

57 LACAN, 1991, p. 102.

${ }^{58}$ DARNTON, 1986, p. 277-328. Refiro-me especificamente ao capítulo: "Os leitores respondem a Rousseau: a fabricação da sensibilidade romântica". 
A obra de Rousseau irá marcar sobretudo as narrativas dos autores das literaturas brasileira e portuguesa, em múltiplos aspectos, que vão desde a concepção da educação à do amor, passando pela de linguagem, tendo como ponto de destaque a inserção do homem na vida social. ${ }^{59}$ Ao relacioná-lo com o que venho discutindo aqui, não trilho os caminhos da velha estilística baseada em temas recorrentes, nem muito menos os do estudo de fontes e de influências. Interessa-me apontar que Machado de Assis é conhecedor desta tradição, bem assim das correntes científicas e estéticas de seu tempo. Muita tinta já foi gasta para ressaltar o quanto Machado soube negar tais correntes. Pouco se disse até agora a respeito de uma posição subjetiva que se traduz ficcionalmente.

Machado tem sido repetidas vezes considerado um escritor amargo, impossível de ser amado, ${ }^{60}$ de muita secura de alma. ${ }^{61}$ Antonio Candido chega a dizer que, segundo Machado de Assis, "não conseguimos agir se não mutilando o nosso eu", que "o que há de mais profundo em nós é no fim de contas a opinião dos outros", e que "estamos condenados a não atingir o que nos parece valioso". E completa: "qual diferença entre o bem e o mal, o justo e o injusto, o certo e o errado?". ${ }^{6}$

59 Cf. STAROBINSKI, 1991.

${ }^{60}$ Cf. ANDRADE, 1974 , p. 89. No capítulo intitulado "Machado de Assis", Mário afirma: "Talvez eu não devesse escrever sobre Machado de Assis nestas celebrações de centenário... Tenho pelo gênio dele uma enorme admiração, pela obra dele um fervoroso culto, mas. Eu pergunto, leitor, pra que respondas ao segredo da tua consciência; amas Machado de Assis?... E esta inquietação me melancoliza. Acontece isso da gente ter às vezes por um grande homem a maior admiração, o maior culto, e não o poder amar."

${ }^{61}$ BARRETO, 1998, p. 284. Cf. carta de Lima a Austregésilo de Ahayde, datada de 19/1/1921: "Gostei que o senhor me separasse de Machado de Assis. Não lhe negando os méritos de grande escritor, sempre achei no Machado muita secura de alma, muita falta de simpatia, falta de entusiasmos generosos, uma porção de sestros pueris. Jamais o imitei e jamais me inspirou."

${ }^{62}$ CANDIDO, 1977, p. 27. 
De fato, o bem e mal, o justo e o injusto, o certo e o errado não estão escritos definitivamente nem nas leis cristãs, nem nas leis médicas, nem muito menos em quaisquer páginas de doutrina estética. Abrir mão do desejo tem conseqüências - e os poderosos também pagam por isso. Isto não significa que os que apostam no que desejam serão felizes para sempre. Não. Pois todo ato tem sua conta de risco, mesmo os dos mais covardes.

Portanto, agora que me encaminho para o término deste ensaio, quero marcar aqui a importância da obra de Machado, por abrir um dimensão nova na mentalidade de sua época, por não submeter seus personagens a nenhuma tese, a nenhuma visão totalizante.

Machado não nega tudo. Até porque isto é impossível. Ele nega algumas verdades coladas à moral do século XIX. Nega a possibilidade de que alguma idéia possa se aplicar a todos com valor universal. Haverá sempre então a dimensão subjetiva. Se o mundo é o que é, isto não é sem a maior ou menor participação de cada um. E esta participação, seja ela qual for, tem um preço. Mostrar este mundo fora das leis de Deus e da ciência não é amargura. E além do mais, pouco espaço mesmo havia para o desejo naquela sociedade. O olhar desconfiado dos narradores de Machado de Assis parece repetir subliminarmente que, neste particular, o rio é estreito e a correnteza é contra.

\section{Referências Bibliográficas}

ANDRADE, Mário. Machado de Assis. Aspectos da Literatura brasileira. 5 ed. São Paulo: Martins, 1974.

ASSIS, Machado. Terpsícore. São Paulo: Boitempo Editorial, 1996.

ASSIS, Machado de. Obra completa. Rio de Janeiro: José Aguilar, $1959,3 \mathrm{v}$.

BARRETO, Lima. Um longo sonbo de futuro. 2 ed. Rio de Janeiro: Graphia, 1998. 
CANDIDO, Antonio. Esquema de Machado de Assis. Vários escritos. São Paulo: Duas Cidades, 1977.

DARNTON, Robert. Os leitores respondem a Rousseau: a fabricação da sensibilidade romântica. O grande massacre de gatos. 2 ed. Rio de Janeiro: Graal, 1986.

FLAUBERT, Gustave. Madame Bovary. São Paulo: Abril Cultural, 1979.

FREUD, Sigmund. O mal-estar na civilização. Obras psicológicas completas de Sigmund Freud. 2. ed. Rio de Janeiro: Imago, 1987.

LACAN, Jacques. O seminário. Livro 7. A ética da psicanálise. Rio de Janeiro: Jorge Zahar Editor, 1991.

MURICY, Kátia. A razão cética. São Paulo: Companhia das Letras, 1988.

SEVCENKO, Nicolau. Introdução. O prelúdio republicano, astúcias da ordem e ilusões do progresso. In: SEVCENKO, Nicolau (org). História da vida privada. São Paulo: Companhia das Letras, 1998.

STAROBINSKI, Jean. A transparência e o obstáculo. São Paulo: Companhia das Letras, 1991.

\section{Resumo}

Este trabalho pretende discutir como a questão do desejo se coloca para os personagens de Machado de Assis em confronto com os ideais construídos pelo cristianismo e pelo saber médico.

\section{Abstract}

This paper aims at discussing as the concept / idea of desire is situated in relation to Machado de Assis' characters, faced by the ideals constructed by Christianity and by medical knowledge. 